\title{
Human Body Food Supply Chain and Inventory Models Analogy: An Empirical Validation
}

\author{
Prem Vrat \\ ITM University, Gurgaon, India \\ Alpana Agarwal \\ ITM University, Gurgaon, India
}

\begin{abstract}
The purpose of this paper is to empirically validate or discard analogies between human body food supply chain and inventory flow in material management based on the paper titled 'Inventory Models and Human Body Food Supply Chain: Some Managerial Insights' by Vrat in which some conjectures were proposed by him . This paper is an attempt to take these conjectures forward to the level of postulates. This is an empirical study administered through two-phase surveys for determining shared perception of a wider group. This study also investigates the effect of age, gender and education on the perception of people on these conjectures. A-G-E (AgeGender-Education) analysis is applied for this purpose. The findings indicate a strong parallel between Vrat's conjectures and survey results. Findings of the A-G-E analysis indicate that the difference in the perception due to demographic factors is significant for many conjectures. It is hoped that this research will bring new insights for managers in handling various issues in a supply chain and also the scientific inventory models can help persons to gain better insights about food intake policies in human body.
\end{abstract}

Keywords: Biomimicry, Human Body Food Supply Chain, Inventory Models, Push System, Fasting

\section{INTRODUCTION}

W hen God created the world, he fashioned many creatures with complex yet efficient and unique designs. Scientists have often tried to duplicate these designs and have met with varying degrees of success. We can also learn and derive solutions to many of our day-to-day problems, conflicts and dilemmas from the principles and systems observed in Nature. This process is called biomimicry, and is an incredible testament of God's superior creation.

We receive the benefits of biomimicry everyday without even realizing it. For example, the tread on the bottom of your shoes is based on the design of dog's paw (Creation Worldview Ministries, n. d.). Also, some types of car tyres are based on the feet of tree frogs, which are able to grip slippery surface without falling (Biology 101, 2012). Even the computers contain biomimicry. The technology which stores programming information in the hard drive, is based on the structure of DNA that carry the coding for every feature of plants, animals and humans (Creation Worldview Ministries, n. d.).

Journal of Technology

Management for Growing Economies

Vol. 5 No. 1 April 2014 pp. 63-79

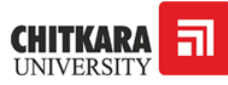

C 2014 by Chitkara University. All Rights Reserved. 
Vrat, P.

Agarwal, A.

However, the greatest of all creations is man himself, the marvelous machineprecise and efficient. We might have the Seven Wonders of the World, but there is no other wonder in the world that can outlive the human body. The human body has a dynamic framework of bone and cartilage called the 'skeleton'. The body has a chemical plant much more complicated than any plant that man has ever built. This plant changes the food we eat into energy. It causes the growth of muscles, blood, bones, teeth etc. When parts are damaged by accident or disease, it even repairs the body. Every intricate design from the tiniest cells to every organ in our body is a concrete evidence of perfection and supremacy.

God has also endowed human beings with a living computer that is infinitely more elaborate and complex, which is the brain. Here the brain is like an (physical) organ while the mind is like an organist. The mind controls the whole man (Hampton, 2012). All our actions, good or bad, have their source in the mind, all the physical organs are servants of the mind, and the nerves are the messengers that transmit its orders to every part of the body, guiding the motions of the living machinery. All our involuntarily functioning mechanisms, that seem to know what to do, at the right time and in the right amount are taken care by brain. These systems are really "autonomous," in doing what they will as it cannot be a coincidence that each time a perfect choice is made out of thousands of possibilities. Our body has evolved so efficiently that we are not even aware that we have the organs that do something for us automatically without consciously controlling it. We are only aware of any organ when something goes wrong. This shows that the nature in its design is flawless. Examples of the nature's perfection are unobstructed supply of oxygen to whole body, recycling of rare resources like blood while discarding of waste (or a material inappropriate for body, but its sources are abundant in nature) like water (Vrat, 2011). These are complicated processes, that we normally take for granted, but there are deep lessons in it. Therefore, when the nature's design is in function, everything goes perfect. However, the areas where the nature has delegated control to the body to use its mind, sub-optimality or non-optimality in the performance of human machinery can be seen. A machine that runs automatically is superior to a machine that must be operated. Hence, we can learn from management science models wherever we need to operate our human machine optimally.

From a systems perspective, human body created by nature is analogous to a business organization in many aspects. Analogies can also be seen between the supply chain of an organization and the supply of food and other life support inputs to the human body. In this background, the flow of oxygen, water, food and other nutrients through the human body can be visualized to constitute a "Bio-Supply Chain". Nature has perhaps managed the material (food and other nutrients) flow through human body in an optimized manner and this analogy can help improve the material flow in physical supply chains in business and industry.

Journal of Technology Management for Growing Economies, Volume 5, Number 1, April 2014 
Also there are dimensions where scientific inventory control models can be used to either develop benchmarks or gain further insights into the biological supply chain learning to manage food and nutrition in a better way (Vrat, 2011). It is hoped that this research will bring useful insights in designing industrial supply chain efficiently learning from the body and also planning and controlling food and water intake learning from the optimal inventory models developed in the context of supply chain.

\section{LITERATURE REVIEW}

\section{Human Body Supply Chain Management}

The task of supply chain management is to manage material flow into, through and out of the system. It has three major segments - inbound flow, manufacturing/ service operations and outbound flow (Shah, 2009). Similarly, the human body food supply chain also has three segments i.e. food intake, digestive operations and waste disposal segment that are supported by a large number of subordinate supply chains and closed loop supply chains. Therefore, the flow of oxygen, water, food and other nutrients through the human body can be visualized to constitute a bio-supply chain. In this context, human body can be perceived as a perfectly designed and managed material flow system and this analogy can help improve the material flow in the physical supply chains in business and industry. Also, the scientific inventory control models can be used to either develop benchmarks or gain further insights into the biological supply chain learning to manage food and nutrition in a better way.

This area of research is quite new and unexplored therefore not much of literature is available. However, analogies between human body and industrial supply chain are developed by few researchers like, Zhang et al (2006) who derived an analogy between transportation of food (through digestion, absorption and blood circulation) to the cell and imbuement of knowledge (through human resource) to an enterprise. They further suggests that by imitating the mechanism of trophic substance (food from which we get energy) transportation process and the principal of bionics and the method of analogy, a bionic model of knowledge supply chain in an enterprise in favour of enterprise knowledge management and its human resource development. An article titled 'What is at the heart of your supply chain?'(Gideon Hillman Consulting, 2012) says that the warehouse in the supply chain and heart in the human body are analogous. Heart in human body supplies approximately 9,000 litres of blood around the body per day. Thus by acknowledging the warehouse of an enterprise as the heart of supply chain, a strategy to maintain the health and longevity of the organization can be developed. According to Singh (2012), human body can be regarded as an organization with various organ systems acting as supply chains. Just as the organs in human body supply chains co-ordinate with each other, the various roles in enterprise supply

Journal of Technology Management for Growing Economies, Volume 5, Number 1, April 2014
Human Body

Food Supply

Chain 
Vrat, P.

Agarwal, A. chains also need to co-ordinate with each other through integrative technologies to ensure effective response to customer needs.

Vrat (2011) in his paper 'Inventory Models and Human Body Food Supply Chain: Some Managerial Insights' has developed some analogies between inventory flow in material management and the food and essential inputs that follow through the human body. In his paper, he has hypothesized that the human body is a 'perfectly engineered system' with optimal design, optimal degree of redundancy to ensure system reliability and optimal degree of flexibility in the design of sub-systems and its elements. To support the hypothesis Vrat (2011) has proposed some conjectures/postulates based on the scientific inventory control models, perceiving human body as a perfectly designed and managed material flow system. These conjectures/postulates can be used by the managers in the design of supply chain, and in the operation part of the food intake. The inventory theory can perhaps guide human beings. These are called 'Vrat's Conjectures' (Vrat, 2011). Table 1 lists the summary of analogies and major recommendations and conjectures by Vrat (2011); marginally paraphrased.

Table 1: Vrat's Conjectures from bio supply chain analogy with scientific inventory control models [derived from Vrat (2011)]

\begin{tabular}{|c|l|l|l|}
\hline S.no. & $\begin{array}{c}\text { Concepts/ Models } \\
\text { from Inventory } \\
\text { Management }\end{array}$ & \multicolumn{1}{|c|}{ Bio-supply chain Analogy } & $\begin{array}{l}\text { Conjectures suggested by } \\
\text { Vrat }\end{array}$ \\
\hline $\mathbf{1}$ & $\begin{array}{l}\text { Just In Time (JIT) } \\
\text { is the best material } \\
\text { replenishment policy } \\
\text { under which the } \\
\text { supplier matches the } \\
\text { supply rate with the } \\
\text { consumption rate and } \\
\text { supplies JIT with 100\% } \\
\text { dependability. }\end{array}$ & $\begin{array}{l}\text { As observed by Vrat (2011), the best } \\
\text { example of real life demonstration } \\
\text { of Zero Inventory system (JIT) } \\
\text { can be seen in bio-supply chain } \\
\text { framework in the context of the } \\
\text { supply of oxygen to the body where } \\
\text { the system operates on with zero } \\
\text { inventories, zero reordering and zero } \\
\text { storage costs. }\end{array}$ & $\begin{array}{l}\text { For A class fast moving, } \\
\text { vital items a 100\% } \\
\text { dependable vendor with } \\
\text { multiple deliveries is the } \\
\text { best material flow option. } \\
\text { Supply chain managers } \\
\text { should benchmark their } \\
\text { supply design decisions } \\
\text { with this. }\end{array}$ \\
\hline $\begin{array}{l}\text { Reverse supply chain or } \\
\text { backward supply chain } \\
\text { is managing efficient } \\
\text { and cost effective } \\
\text { flow of raw materials, } \\
\text { in-process inventory, } \\
\text { finished goods \& related } \\
\text { information from the } \\
\text { point of consumption } \\
\text { to the point of origin } \\
\text { for the purpose of } \\
\text { recapturing value or } \\
\text { proper disposal. }\end{array}$ & $\begin{array}{l}\text { Bio-supply chain can differentiate } \\
\text { the necessarily required inputs } \\
\text { among all the inputs to the body, } \\
\text { and further digestion and absorption } \\
\text { is done accordingly. Undesirable } \\
\text { input/output is flushed unprocessed } \\
\text { out like in a push system. But vital } \\
\text { body elements like blood are re } \\
\text { circulated after removing of toxic } \\
\text { contents through network of arteries } \\
\text { \& veins as can't be synthesized } \\
\text { synthetically. Only absolute waste or } \\
\text { toxic substances are exited through } \\
\text { urinary track. }\end{array}$ & $\begin{array}{l}\text { Reduce, reuse, recycle } \\
\text { conjecture, wherever } \\
\text { applicable could be used } \\
\text { in both inventory and bio } \\
\text { supply chain. The best } \\
\text { way to manage waste is to } \\
\text { generate minimum (reduce) } \\
\text { with a preventive focus, } \\
\text { make most out it by reuse } \\
\text { by recycling like blood } \\
\text { recycling in human body. } \\
\text { Reverse supply chain design } \\
\text { may learn from this. }\end{array}$ \\
\hline
\end{tabular}

Journal of Technology Management for Growing Economies, Volume 5, Number 1, April 2014 


\begin{tabular}{|c|c|c|c|}
\hline S.no. & $\begin{array}{l}\text { Concepts/ Models } \\
\text { from Inventory } \\
\text { Management }\end{array}$ & Bio-supply chain Analogy & $\begin{array}{c}\text { Conjectures suggested by } \\
\text { Vrat }\end{array}$ \\
\hline 3 & $\begin{array}{l}\text { Centralization of } \\
\text { storage location of an } \\
\text { expensive commodity is } \\
\text { an optimal strategy in a } \\
\text { multi-echelon inventory } \\
\text { system. }\end{array}$ & $\begin{array}{l}\text { Nature has designed it by } \\
\text { centralization of the storage and } \\
\text { distribution of human blood through } \\
\text { heart-as an extremely reliable pump } \\
\text { with huge life expectancy to supply } \\
\text { purified blood to various body cells. }\end{array}$ & $\begin{array}{l}\text { This analogy can be very } \\
\text { insightful in designing } \\
\text { material flow in a two level } \\
\text { supply system- central store } \\
\text { and retail outlets. Speed } \\
\text { of flow can be adjusted } \\
\text { depending upon the need. }\end{array}$ \\
\hline 4 & $\begin{array}{l}\text { Procurement, production } \\
\text { and distribution based } \\
\text { on demand (pull system) } \\
\text { is better than one based } \\
\text { only on forecast (push } \\
\text { system) of material flow. }\end{array}$ & $\begin{array}{l}\text { Food intake depending purely on } \\
\text { appetite and food intake at fixed } \\
\text { scheduled times irrespective of } \\
\text { the level of appetite respectively } \\
\text { constitute the pull and push system } \\
\text { of bio-supply chain. }\end{array}$ & $\begin{array}{l}\text { It is desirable to take food } \\
\text { based only on level of } \\
\text { appetite. Eating without } \\
\text { hunger only adds fat to the } \\
\text { body. }\end{array}$ \\
\hline 5 & $\begin{array}{l}\text { Staggered supplies } \\
\text { at a rate higher than } \\
\text { consumption rate } \\
\text { is better than entire } \\
\text { replenishment supplied } \\
\text { in a single lot and } \\
\text { improve supply chain } \\
\text { performance. }\end{array}$ & $\begin{array}{l}\text { Taking few meals of small quantity } \\
\text { and intake of huge size meal only } \\
\text { once or twice a day to fulfill the } \\
\text { body nutritional requirement are } \\
\text { analogous to staggered supplies and } \\
\text { one time replenishment of the lot of } \\
\text { supply chain respectively. }\end{array}$ & $\begin{array}{l}\text { Eating small quantities } \\
\text { of food more frequently } \\
\text { is better than taking huge } \\
\text { sized meal once or twice } \\
\text { a day. }\end{array}$ \\
\hline 6 & $\begin{array}{l}\text { The optimal degree } \\
\text { of backlogging is a } \\
\text { function of cost of } \\
\text { shortage. For finite } \\
\text { shortage cost, it is } \\
\text { beneficial to permit } \\
\text { planned backlogging } \\
\text { as it improves overall } \\
\text { system performance. }\end{array}$ & $\begin{array}{l}\text { In bio supply chain, backlogging is } \\
\text { skipping or delaying intake of items } \\
\text { like oxygen, water and food based } \\
\text { on vital-essential-desirable category. } \\
\text { Permissible level of backlogging } \\
\text { depends on the level of harm of not } \\
\text { supplying these food items when } \\
\text { needed. }\end{array}$ & $\begin{array}{l}\text { The oxygen being 'vital', } \\
\text { no backlogging is allowed; } \\
\text { but for water (an essential } \\
\text { item), delayed intake of } \\
\text { 1-2 hours after meals may } \\
\text { help. For food items that } \\
\text { come under 'desirable' } \\
\text { category a day's fast in a } \\
\text { week is perhaps desirable. } \\
\text { This brings out inventory } \\
\text { theoretic justification of } \\
\text { delaying water intake } \\
\text { immediately after main } \\
\text { meals and of 'fasting' or } \\
\text { Vrat (missing meals) say } \\
\text { once a week. This perhaps } \\
\text { may improve digestive } \\
\text { system performance. }\end{array}$ \\
\hline
\end{tabular}

\section{Human Body Food Supply Chain}


Vrat, P.

Agarwal, A.

\begin{tabular}{|c|l|l|l|}
\hline S.no. & $\begin{array}{c}\text { Concepts/ Models } \\
\text { from Inventory } \\
\text { Management }\end{array}$ & \multicolumn{1}{|c|}{ Bio-supply chain Analogy } & $\begin{array}{c}\text { Conjectures suggested by } \\
\text { Vrat }\end{array}$ \\
\hline 7 & $\begin{array}{l}\text { Inventory research } \\
\text { involving extensive } \\
\text { simulation based } \\
\text { experimentation } \\
\text { suggests that for } \\
\text { periodic replenishment } \\
\text { policy, }(\mathrm{s}, \mathrm{S}, \mathrm{T}) \text { policy } \\
\text { is better than }(\mathrm{S}, \mathrm{T})\end{array}$ & $\begin{array}{l}\text { In context of human body, } \mathrm{S}, \mathrm{T}) \\
\text { policy is planned supply of food to } \\
\text { the body to maintain the periodicity } \\
\text { of food intake irrespective of the } \\
\text { level/extent of appetite while (s,S,T) } \\
\text { policy is delaying or skipping food } \\
\text { intake from the planned periodicity } \\
\text { if the level of appetite is not }\end{array}$ & $\begin{array}{l}\text { It is opined from this } \\
\text { analogy that instead of } \\
\text { mandatorily loading the } \\
\text { human body with food at } \\
\text { fixed time interval, it is } \\
\text { good to defer food intake to } \\
\text { the next period if the level } \\
\text { of appetite is low. }\end{array}$ \\
\hline
\end{tabular}

inventory policy.

$(\mathrm{S}, \mathrm{T})$ policy leads

to unnecessary

replenishment and

unnecessary addition

to the stock even when

there is adequate stock

in hand.

8 Slow moving items are those that are required at some specific situations rather than in routine.

Stocking such SMIs is not recommended.

9

Strategies must be

designed to reduce

transportation cost,

which is a non value

added proposition.

Slurry transportation

along with gravity

approach facilitates

material flow with less

cost and efforts.

10

An optimal and

economic waste disposal

frequency is a tradeoff

between cost of holding

and cost of disposing off

and the storage capacity

available.

In case of human body supply chain, diet supplements, vitamins and some medicines are part of SMIs. These

SMIs are not required by human

body in routine and give adequate

warning before these are needed as in case of inventory management.

Using appropriate postures during

food intake to facilitate food

flow through bio supply chain is

analogous to using gravity for

facilitating transportation. Chewing

food sufficiently to make slurry

further supports the material flow in

bio supply chain.

Frequency of waste disposal in human body depends on the storage capacity available. Like e.g. $\mathrm{CO} 2$, the respiratory system waste is continuously disposed off; whereas for liquid waste, there is adequate storage capacity and the disposal is planned as per convenience. For solid waste the storage capacity is even higher and thus disposal is planned accordingly.
The intake of such

infrequent items should be on demand pull driven basis and not to be pushed into human body regularly.

The conjecture is that it is not advisable to eat while lying down as gravity does not work, hampering the food flow. Also it is desirable to chew food extensively to make slurry of food for smooth, easy and cost effective flow.

Push system works better than reducing the frequency of disposal in reverse supply chain.

These conjectures show new and very powerful directions for research based on biological system analogy to industrial supply chain management and inventory control. However, the conjectures developed are his personal

Journal of Technology Management for Growing Economies, Volume 5, Number 1, April 2014 
opinions at this stage and need to be validated before acceptance. To check the validity of these conjectures and see if these conjectures can be taken ahead to the level of postulates, we have conducted a questionnaire-based survey and collected opinion of wider group of people based on their personal real life experiences.

Considering the present lifestyle of people and role of eating habits and practices in the maintenance of health, and the prevention of disease, this study may provide new and powerful insights in improving food and water intake habits.

Although, the research addressing industrial supply chain issues from human body perspective is not initiated by any researcher but research covering healthier eating habits in human is taken by few. For example, various spiritual organizations and groups have suggested fasting for purification of soul, but until the early 1900s, its benefits to the body were limited to treat various disorders like diabetes, obesity and epilepsy (Stipp, 2013). According to Stipp (2013), intermittent fasting that includes everything from skipping a meal or two on certain days of the week to periodic multiday fasts may promote many health benefits. Other way to keep body fit and healthy is routine calorie restriction. However, according to PRNewswire (2013b), practice of both regular calorie restriction and intermittent fasting can jerk the body around. 'Therefore, to take advantage of the importance of time away from food, LivingTheCRWay. com, scientists suggests Daily Intermittent Fasting as a balanced way to work the benefits of fasting plus the benefits of letting your body adjust to a regular routine'(PRNewswire, 2013b). A recent study at American Hospital Dubai, spearheaded by Chief Interventional Cardiologist Dr Omar Hallak has revealed that fasting can reduce bad cholesterol and can provide long-term health benefits (Pakistan Today, 2013). In addition to skipping meal for a better digestion, researchers also found that three short post-meal walks at an easy tomoderate pace is an effective way to reducing blood sugar (Daily Mail, 2013).

Another important concern related with healthy body is the posture to be followed while eating. A recent article suggests from Shape Magazine suggests that sitting is the best posture when a person is eating. In this article, a nutritional consultant explains, "Digestion is a process dominated by our parasympathetic nervous system, which has the famous tagline 'rest and digest' - your body needs to be relaxed in order to process food efficiently, so it makes sense that we should also try to relax while eating" (PR Newswire, 2013a).

To stay healthy Parks \& McCrory (2005) suggests that it is better to eat several small meals a day rather than two or three large ones. Another important area of concern, to keep the body healthy is regarding post meal water intake.
Human Body

Food Supply

Chain

Journal of Technology Management for Growing Economies, Volume 5, Number 1, April 2014 
Vrat, P.

Agarwal, A.
Geter (2012) expressed concern that drinking water during or immediately after meal dilutes the digestive enzyme concentrations, thereby making it hard to assimilate food. One should wait about an hour post meal to take water and then after drinking water wait about half an hour to eat again.

\section{Need for the Study}

Supply chain management has always been a major concern for manufacturing

and other industries. On the other hand, health issues arising due to eating routine has always troubled people. Through this research, we have tried to provide some solutions for both. This study is conducted to accept or discard the insights suggested by Vrat (2011) on various issues related with industrial and human body food supply chain. Agreement/disagreement of wider group of people on Vrat's conjectures might persuade researchers to take this study ahead to validate or discard the conjectures by extensive experimentation under controlled conditions. This research will help industries and humans in better management of their respective supply chain.

The result of this empirical study would validate or discard the conjectures derived by Vrat (2011) with respect to human body. Validation of these conjectures in human body will open up new directions in designing industrial supply chain. These postulates, if found valid in managing supply chain in human body (which is nature's most complex and perfect organization); would definitely help industries in planning solutions to their inventory supply chain problems.

The results of the present study conducted on Vrat's conjectures suggest important learning for human body food intake habits which need to be further validated by medical researchers and if found positive, may strengthen the Vrat's postulates.

\section{RESEARCH METHODOLOGY}

\section{Objectives}

The objective of the present study is to verify and validate the conjectures given in a paper, termed as "Vrat's Conjectures" that were then considered his personal opinions based on scientific inventory control models. The objective also covers analysing the impact of demographic profile of respondents on their perception about these conjectures. Although some of these conjectures might look straight away acceptable even intuitively, but these must be verified and validated before generalizing, using feedback from an adequate number of people based on their own experience.

Journal of Technology Management for Growing Economies, Volume 5, Number 1, April 2014 


\section{Hypothesis}

The objectives mentioned above have led to proposing the following testable hypotheses:

Hypothesis 1 (HY 1): Select conjectures based on scientific inventory control models perfectly replicate optimal food intake policies for an effective and efficient operation of human body food supply chain.

Hypothesis 2 (HY 2): The age group of people significantly influences their perception on the select conjectures.

Hypothesis 3 (HY 3): The differences in the perceptions on select conjectures are significantly gender sensitive.

Hypothesis 4 (HY 4): The educational background of the people significantly influences their perception on the select conjectures.

\section{Sampling}

To test these hypotheses, an empirical study was designed. This research was administered in two phases wherein Phase I survey was administered to gather information on the perception of people on the parameters discussed in 'Vrat's Conjectures'. Phase II survey was administered to strengthen the outcomes of the Phase I survey as the respondent's strong agreement with an option to a statement doesn't mean disagreement with others and vice- versa.

\section{Area considered for study -Delhi NCR}

Convenience sampling approach was followed for phase I survey wherein the subjects that were available to participate in the research study viz., friends, students, or colleagues were included. The questions asked are quite general in nature and can be responded by every kind of people irrespective of their age, gender and education. However, we have tried to inculcate respondents of varying age, gender and education to achieve a sample that is best possible representative of the population.

For Phase I survey, a significant sample size of 400 was targeted in order to reduce the chances of biases and outliers due to various demographic characteristics. For phase II survey, the sampling size was reduced to half (i.e. 200) because the purpose of phase II survey was just to revalidate the outcomes of phase I survey.

The subjects for phase II survey was the same as that for phase I survey. The process used to track the subjects out of phase I include listing down all the phase I respondents and selecting every alternate respondent out of it to constitute the phase II sample.

Journal of Technology Management for Growing Economies, Volume 5, Number 1, April 2014
Human Body

Food Supply

Chain 
Vrat, P.

Agarwal, A.

\section{Data Collection}

Primary data were collected by conducting survey in two phases using different structured questionnaires. The questionnaire for phase I survey was split into two sections. First section was designed to know the demographic profile of the respondents while the questions in the second section were asked with the intent to know the perception/understanding of people on practices related to food, water and dietary supplement intake, based on their personal experience. There were 10 major items in the questionnaire that are drawn from the "Vrat's Conjectures". Each item in the questionnaire was related to a specific conjecture that further contained a set of five statements related to that item only. In this way, the questionnaire contained 50 items in all. The respondents were required to mark their agreement or disagreement to each statement on a five point Likert scale ranging from 'strongly disagree' to 'strongly agree'. Overall degree of favour marked by respondents to statements in each set will decide the validation or rejection of the related conjecture. To quantify the qualitative data, we will take ' 1 ' for strongly disagree and ' 5 ' for strongly agree.

Phase II survey was administered to reinforce the outcomes of the Phase I survey. Items in the questionnaire were based on the statements that emerged as the most agreed average perception (highest average score) of the respondents. In this survey, the respondents were supposed to mark their agreement or disagreement to the items in the questionnaire. Only the respondents of the first survey became part of the second survey.

\section{Analysis}

Cronbach's alpha is applied to check the internal consistency of the items in both the questionnaires. The interpretation of responses for validation of conjectures has been done using statistical measures viz., average, dispersion and coefficient of variation. Demographic variables viz., age, gender and education are determined considering the fact that it may have direct effect on the opinion of people and to gauge the effect of demographic variables on respondents' most favoured items, Chi-square test at $5 \%$ significance level has been applied. The findings of chi-square test adjudicate whether the differences observed in the opinion of the respondents are because of their demographic profile. This section of the analysis is named A-G-E analysis after abbreviation of major demographic factors (Age, Gender and Education) included under the study. The purpose of doing AG-E Analysis was to understand the impact of age, gender and education on the opinion of the people towards the conjectures. If the analysis leads to converging opinion of people then it would reinforce the strength of conjectures.

A-G-E analysis will broadly involve grouping each demographic factor

Journal of Technology Management for Growing Economies, Volume 5, Number 1, April 2014 
(Age, Gender, and Education) into two categories. For this purpose, age of respondents is categorised as below 30 years and 30 years \& above as the perception regarding meal planning of an individual start changing at 30's. Also, categorization of respondents on the basis of education and gender was done considering that mindset of people about fundamental eating habits differs with education among males and females. Therefore, opinion of people regarding Vrat's conjectures might also differ with demographic profile of individuals. Gender is already dichotomous while educational background has been segregated as undergraduates and postgraduates.

\section{FINDINGS AND DISCUSSIONS}

\section{Reliability Testing}

The value of Cronbach's $\alpha$ (for Phase I survey is 0.758 and 0.71 for Phase II survey) as computed by Cronbach's alpha test lies in the acceptance range. This proves that both the questionnaires are internally consistent and the results of surveys are reliable.

\section{Testing Vrat's Conjectures}

\section{Analysis of Phase I Survey}

Mean value of the points assigned to responses on each item shows the degree of favour to that item. The statement that has got the highest mean value among others under the same item represents not only the most agreed viewpoint but will also decide validation or rejection of related conjecture as the case may be.

Table 2: Most agreed statements on a 5 point rating scale in Phase I survey with their mean values, standard dev and Coeff. of variation

\begin{tabular}{|c|l|c|c|c|}
\hline $\begin{array}{c}\text { S. } \\
\text { No. }\end{array}$ & Statements with highest rating & $\begin{array}{l}\text { Mean } \\
\text { Value }\end{array}$ & $\begin{array}{l}\text { Std. } \\
\text { Deviation }\end{array}$ & $\begin{array}{l}\text { Coefficient } \\
\text { of Varia- } \\
\text { tion }\end{array}$ \\
\hline a. & $\begin{array}{l}\text { Food intake purely depending upon the level/ } \\
\text { extent of appetite. }\end{array}$ & 3.63 & 1.00 & 0.28 \\
\hline b. & $\begin{array}{l}\text { Take few small meals as and when feel hungry } \\
\text { to fulfil body appetite and nutritional require- } \\
\text { ment. }\end{array}$ & 3.40 & 1.05 & 0.31 \\
\hline c. & $\begin{array}{l}\text { Take small gap of about one hour to drink water } \\
\text { after the meal. }\end{array}$ & 3.75 & 1.01 & 0.27 \\
\hline d. & Skip a single meal any day once a week. & 3.03 & 1.26 & 0.42 \\
\hline e. & $\begin{array}{l}\text { Take diet supplement, special medication, } \\
\text { vitamin supplements only on demand (illness or } \\
\text { its symptoms). }\end{array}$ & 3.59 & 1.00 & 0.28 \\
\hline
\end{tabular}


Vrat, P.

Agarwal, A.

\begin{tabular}{|c|l|c|c|c|}
\hline $\begin{array}{c}\text { S. } \\
\text { No. }\end{array}$ & Statements with highest rating & $\begin{array}{l}\text { Mean } \\
\text { Value }\end{array}$ & $\begin{array}{l}\text { Std. } \\
\text { Deviation }\end{array}$ & $\begin{array}{l}\text { Coefficient } \\
\text { of Varia- } \\
\text { tion }\end{array}$ \\
\hline f. & $\begin{array}{l}\text { Take food in small quantity to maintain pe- } \\
\text { riodicity of food intake if the level/extent of } \\
\text { appetite is not adequate. }\end{array}$ & 3.66 & 0.91 & 0.25 \\
\hline g. & $\begin{array}{l}\text { Chew sufficiently to make slurry of the food for } \\
\text { its smooth passage from mouth to stomach. }\end{array}$ & 3.87 & 0.89 & 0.23 \\
\hline h. & $\begin{array}{l}\text { Sitting is the ideal posture for food intake for } \\
\text { smooth passage of the food from mouth to } \\
\text { stomach for digestion. }\end{array}$ & 4.35 & 0.81 & 0.19 \\
\hline i. & $\begin{array}{l}\text { Slow walk after a small gap of time after food } \\
\text { intake is good for the better digestion of food. }\end{array}$ & 3.25 & 1.20 & 0.37 \\
\hline j. & $\begin{array}{l}\text { It is better to go to the restroom as frequently as } \\
\text { one needs, irrespective of the normal frequency. }\end{array}$ & 3.55 & 0.99 & 0.28 \\
\hline
\end{tabular}

The issue based findings and discussions are discussed in the following paragraphs.

'Food intake based purely on appetite' had the highest average of 3.63 pertaining to practices adopted by the respondents regarding food intake periodicity. This clearly shows that in human body food supply chain pull system i.e. food intake purely on appetite is better than push system i.e. food intake at scheduled time irrespective of the level of appetite.

On the view recommending ideal size of meal to be taken along with its periodicity to fulfill the body appetite, highest average of 3.4 indicates that people believe more in 'taking small meals periodically', that too on felt appetite only. This perception of the respondents validates Vrat's second conjecture from inventory models for human supply chain that replenishing the food supply in small quantities (called as staggered supplies in inventory management) is better than fulfilling the whole of the body requirement in a single meal.

Highest average value (3.75) for the variable 'take small gap of about one hour to drink water after the meal' shows that the people believe that it is good to delay water intake by a small duration of about one hour after food intake. This supports Vrat's conjecture of planned backlogging of essential items for some time as the cost of shortage i.e. loss to the body in delaying water intake for some time immediately after food intake is not catastrophic.

Similarly, 'skipping a single meal any day once a week' had the highest value of mean (3.03) supporting the conjecture which suggests that in case of desirable items like solid food, a relatively higher backlog level may help improving bio supply chain performance. However, the support is relatively weak. 
The highest mean value (3.59) supports the view of 'taking diet Human Body supplement or other type of medication only when demanded by the body'. Vrat's conjectures considered these supplements to be analogous to slow moving items in inventory management. The responses validates the Vrat's conjecture suggesting do not stock slow moving items, but take an immediate and expedited procurement action using just in time (JIT) concepts.

The opinion of 'reducing the size of food when the level of appetite is not adequate to maintain the periodicity of food intake' has a strong agreement of respondents (with a highest average of 3.66). This justifies the opinion that instead of mandatorily loading the human body with food intake at fixed time interval, it is good to reduce the size of meal if the level of hunger is low. This is similar to optional replenishment inventory policy.

Regarding food chewing pattern and suggested posture during food intake, highest average value (3.87) lies with 'chewing sufficiently to make the slurry of the food'. Also, sitting posture is suggested by most respondents during food intake for facilitating the smooth flow of food through food canal for better digestion (highest average 4.35). This validates another Vrat's conjecture that one should chew the food sufficiently to make it pulpy while using gravity that pushes the slurry down the bio supply chain by reducing the efforts on food transportation.

Vrat's conjecture suggesting the use of gravity in reducing efforts in transportation of food from mouth to the digestion site is supported by the respondents as the highest average (3.35) connects with the statement suggesting 'a mild walk after food intake for better digestion and absorption of food'.

On the view about the reverse bio-supply chain management, "it is better to go to the restroom as frequently as one needs, irrespective of the normal frequency' had highest mean (3.55). This suggests that for reverse supply chain management or for waste management the push system is better than pull system. This is very insightful observation as pull system has been so much hyped in supply chain. However, for reverse supply chain, a push system should be better.

The values of standard deviation and coefficient of variation (refer Table 2) reflects the amount of variation in the opinion. Lowest standard deviation (0.81) shows relative consistency in the opinion on the item suggesting sitting as the best posture for taking food. Highest value of standard deviation (1.26) reflects a relatively divided opinion on the item recommending skipping a meal once a week for improved digestion. Supporting our first hypothesis, the values of coefficient of variation for most items is quite low. For example, the statement suggesting sitting as an ideal posture for food intake and chewing the 
Vrat, P.

Agarwal, A. food sufficiently are most consistent views with lowest $C_{v}$ values 0.19 and 0.23 respectively. On other hand relatively high variation $\left(\mathrm{C}_{\mathrm{v}}=0.42\right)$ can be seen in the opinion of people on the item recommending to skip a meal once a week. This indicates how far the individual responses on this question vary from the average. This can be further justified by relatively low level of agreement by people (77 percent) on the same item in Phase II survey (refer Table 3).

Statistics in the Table 2 shows that most agreed statements (one with highest mean, low standard deviation and low $\mathrm{C}_{\mathrm{v}}$ ) from each set validate the Vrat's Conjectures of bio-supply chain management. But if we look at the mean value for each statement within an item, it shows that though most respondents were strongly agreed with the statements validating Vrat's conjectures but they did not even deny other statements (as their mean values are non zero). Results of the second survey will reflect the respondent's either absolute agreement or disagreement on the select parameter thus providing additional support in accepting or rejecting the conjectures. Need for Phase II survey was felt to have a conclusive evidence of accepting or rejecting a conjecture.

\section{Analysis of Phase II Survey}

It is evident from the findings of Phase II survey (refer Table 3) that most respondents agreed with the recommendations from Vrat's conjectures. In fact, the percent agreement is much higher, than anticipated which gives a greater confidence in accepting these conjectures.

Table 3: Status of agreement by \% respondents in Phase II survey

\begin{tabular}{|c|l|c|}
\hline $\begin{array}{c}\text { S. } \\
\text { No. }\end{array}$ & Statements with highest rating/ Recommendations from Vrat's \\
Conjectures & $\begin{array}{l}\text { \% age respon- } \\
\text { dents who } \\
\text { agreed with } \\
\text { Conjecture }\end{array}$ \\
\hline a & $\begin{array}{l}\text { Food intake based on level/extent of appetite is better than eating } \\
\text { periodically at fixed time irrespective of the hunger. }\end{array}$ & 79 \\
\hline b & $\begin{array}{l}\text { Eating small quantities of food more frequently is better than tak- } \\
\text { ing huge meal once or twice a day. }\end{array}$ & 93 \\
\hline c & $\begin{array}{l}\text { Delaying water intake up to 1-2 hours after meals can help in bet- } \\
\text { ter digestion of food. }\end{array}$ & 83 \\
\hline d & $\begin{array}{l}\text { Fasting once in a week may help improve body digestive system } \\
\text { performance. }\end{array}$ & 77 \\
\hline e & $\begin{array}{l}\text { Taking diet supplements, special medication, and vitamin supple- } \\
\text { ments etc. regularly is not desirable; it should only be taken on } \\
\text { prescription based on the demand. }\end{array}$ & 91 \\
\hline & $\begin{array}{l}\text { If the food intake has to be in a periodic intervals and the level/ } \\
\text { extent of appetite is not adequate, then it is better to reduce the size } \\
\text { of meals for better digestive system performance. }\end{array}$ & \\
\hline
\end{tabular}

Journal of Technology Management for Growing Economies, Volume 5, Number 1, April 2014 


\begin{tabular}{|c|l|c|}
\hline $\begin{array}{c}\text { S. } \\
\text { No. }\end{array}$ & $\begin{array}{l}\text { Statements with highest rating/ Recommendations from Vrat's } \\
\text { Conjectures }\end{array}$ & $\begin{array}{l}\text { \% age respon- } \\
\text { dents who } \\
\text { agreed with } \\
\text { Conjecture }\end{array}$ \\
\hline g & $\begin{array}{l}\text { It is desirable to chew food sufficiently to facilitate the slurry } \\
\text { movement through food canal for improved digestion. }\end{array}$ & 95 \\
\hline h & $\begin{array}{l}\text { Sitting is the recommended posture for food intake, as eating while } \\
\text { lying down may hinder the movement of food through the diges- } \\
\text { tive canal. }\end{array}$ & 93 \\
\hline i & $\begin{array}{l}\text { It is good to go for a slow walk after a small gap of time after food } \\
\text { intake for improved digestive system performance. }\end{array}$ & 96 \\
\hline j & $\begin{array}{l}\text { It is better to go to restroom as frequently as one needs holding solid } \\
\text { or liquid body waste to maintain the normal frequency is not good. }\end{array}$ & 89 \\
\hline
\end{tabular}

Human Body

Food Supply

Chain

Thus, the outcomes of Phase I survey along with that of Phase II support the first hypothesis. Based on these findings, the first hypothesis that conjectures based on scientific inventory control models by Vrat (2011) conform to optimal food intake policies for an effective and efficient operation of human body as a food supply chain.

\section{A-G-E Analysis}

In Table 4, findings of the chi-square test show a significant difference in the mean value of responses due to difference in the level of agreement by the respondents based on their demographic profile like age, gender and education. For some items, the difference seen in the mean value is not significant. Highlighted cells in Table 4 show the parameters where the difference in the opinion (mean values of respondent) due to demographic variable is statistically significant at $5 \%$ level of significance.

Table 4: Findings of chi-square test at 5\% level of significance applied on responses of Phase I survey

\begin{tabular}{|c|c|c|c|c|c|c|c|c|c|c|c|c|c|}
\hline $\begin{array}{c}\text { Hypoth- } \\
\text { esis No. }\end{array}$ & Age & $\begin{array}{c}\text { Gen- } \\
\text { der }\end{array}$ & $\begin{array}{c}\text { Educa- } \\
\text { tion }\end{array}$ & $\mathbf{a}$ & $\mathbf{b}$ & $\mathbf{c}$ & $\mathbf{d}$ & $\mathbf{e}$ & $\mathbf{f}$ & $\mathbf{g}$ & $\mathbf{h}$ & $\mathbf{i}$ & $\mathbf{j}$ \\
\hline HY 2 & $\begin{array}{c}<30 \\
\text { years }\end{array}$ & & & 3.62 & 3.64 & 3.84 & 2.91 & 3.57 & 3.58 & 4.03 & 4.33 & 3.19 & 3.58 \\
\hline HY 2 & $\begin{array}{c}>30 \\
\text { years }\end{array}$ & & & 3.64 & 3.18 & 3.67 & 3.13 & 3.61 & 3.73 & 3.73 & 4.36 & 3.31 & 3.52 \\
\hline HY 3 & & Male & & 3.66 & 3.24 & 3.73 & 3.15 & 3.57 & 3.79 & 3.77 & 4.36 & 3.33 & 3.55 \\
\hline HY 3 & & Female & & 3.58 & 3.65 & 3.78 & 2.83 & 3.62 & 3.44 & 4.03 & 4.33 & 3.14 & 3.54 \\
\hline HY 4 & & & $\begin{array}{c}\text { Under- } \\
\text { graduate }\end{array}$ & 3.62 & 3.48 & 3.73 & 3.08 & 3.76 & 3.80 & 3.97 & 4.32 & 3.28 & 3.38 \\
\hline HY 4 & & & $\begin{array}{c}\text { Post- } \\
\text { graduate }\end{array}$ & 3.64 & 3.33 & 3.76 & 2.98 & 3.45 & 3.54 & 3.79 & 4.37 & 3.23 & 3.69 \\
\hline
\end{tabular}


Vrat, P.

Agarwal, A.

From Table 4, significant variations in the opinion of the people due to differences in age can be seen for items b, d, e, g, h, i and j. On the other hand, the differences in the mean value for $\mathrm{a}, \mathrm{c}$ and $\mathrm{f}$ items are because of chance. Therefore, we can say that the items b, d, e, g, h, i and $\mathrm{j}$ support the second hypothesis and others are not supported. The people who are less than 30 years in age agree more strongly with $b, g$, and $j$ parameters whereas people who are above 30 years in age agree more strongly with $\mathrm{d}, \mathrm{e}, \mathrm{h}$ and i parameters .

Observed differences in the opinion by males and females are significant only in items a, b, e, f and g. From Table 4, it is clear that the male respondents agree more with statement $\mathrm{a}$ and $\mathrm{f}$ than females while females agree more with statement $b$, e and $g$ than males. As per the statistics, difference in mean values of a, e, f and $g$ items support hypothesis 3 while $c, d, h, i$ and $j$ are not supported.

Respondents who are postgraduates favour statement $\mathrm{c}, \mathrm{h}$ and $\mathrm{j}$ more strongly than those who are undergraduates. On the other hand UG and graduate people agree more with d, e, f, $g$ and i than others. Differences in the mean values of $a$ and $b$ items are found to be insignificant. From these statistics, it is evident that differences in the mean values for all the items except these items support the hypothesis 4 that the educational background of the people significantly influences their perception on select parameters.Conclusions and Recommendations

\section{CONCLUSIONS AND RECOMMENDATIONS}

Responses from both surveys support Vrat's conjectures hence, we are in a position to accept HY1. Inferences drawn from A-G-E analysis suggest that respondents' views on majority of items are supporting HY2, HY3 and HY4 while views on some items are against it. HY2, HY3 \& HY4 are therefore partially acceptable. Further analysis is required in the previously mentioned areas to accept or reject these hypotheses. However, it suggests that while pull system is good for forward supply chain, a push system of material flow is a better strategy in reverse supply chains.

The result of this empirical study validates the conjectures derived by Vrat with respect to human body. These postulates, if found valid in managing supply chain in human body (which is nature's most complex and perfect organization); would definitely help industries in planning solutions to their inventory supply chain problems. This paper is about practices by people crucial for a healthy living and the findings are based on shared perception of common people. Therefore, we cannot generalize and recommend these postulates at this stage. In order to accept them, it needs to be verified and validated through extensive medical experimentation under controlled conditions. It is believed that this paper will open up new area of interdisciplinary research inspired by

Journal of Technology Management for Growing Economies, Volume 5, Number 1, April 2014 
the biological system in supply chain context. However, it does take forward the conjectures to the level of postulates.

\section{REFERENCES}

Biology 101 (2012) 'What Snow Tires and Tree Frogs Have in Common?', Biology 101.Org, (online) (cited 23 July 2013) Available from URL: <http://www.biology101.org/archive/2012/12/whatsnow-tires-and-tree-frogs-have-in-common/ $>$.

Creation Worldview Ministries (n.d.) 'Biomimicry-God's Designs and Man's Imitations', (online) (cited 23 July 2013), Available from URL:<http://www.creationworldview.org/articles_view. asp?id=119>

Daily Mail (2013) 'A 15-minutes walk after eating cut diabetes risk', Regional Business News, Daily Mail, 13 June, (online) (cited 30 June 2013) Available from Ebscohost database.

Geter, L., (2012) 47 Steps to Stress Management Real Help for Stress Relief and the Prevention of Premature Aging, Forward Enterprises LLC, (online) (cited 14 June 2013) Available from: URL: $<$ http://books.google.co.in/books?id=G8x9AzArCuIC\&printsec=frontcover\&dq $=47+\mathrm{S}$ teps+to+Stress+Management+Real+Help+for+Stress+Relief+and+the+Prevention+of+Prem ature+Aging+books\&hl=en\&sa $=X \&$ ei $=c 534 \mathrm{UaPvEoHVrQegw}$ YHQDQ\&ved=0CC8Q6AE wAA\#v=onepage $\& q=47 \% 20$ Steps $\% 20$ to $\% 20$ Stress $\% 20$ Management $\% 20$ Real $\% 20 \mathrm{Help} \% 20$ for $\% 20$ Stress $\% 20$ Relief $\% 20$ and $\% 20$ the $\% 20$ Prevention $\% 20$ of $\% 20$ Premature $\% 20$ Aging $\% 20$ books\&f=false $>$.

Gideon Hillman Consulting (2012)'What is at the heart of your supply chain?, Supply Chain \& Logistics Specialists, Gideon Hillman Consulting, (online) (cited 17 December 2013) Available from URL:<http://www.hillman-consulting.co.uk/articles/featured-articles/warehousing.html>.

Hampton, D. (2012) 'The Mind And The Brain: What's The Difference?, The Best Brain Possible', (online) (cited 23 July 2013) Available from URL:<http://www.thebestbrainpossible.com/themind-and-the-brain-what-is-the-difference>.

Pakistan Today (2013) 'Fasting is good for Heart: Study', 9 July, Pakistan Today, (online) (cited 30 June 2013) Available from Ebscohost database.

Parks, E.J. and McCrory, M.A. (2005) 'When to Eat \& How Often?', The American Journal of Clinical Nutrition, 81:1, pp. 3-4.

PR Newswire (2013a) 'Hydroxycut: Sitting while Eating can assist Digestion and Weight loss', $P R$ Newswire, US, 8 January, (online) (cited 30 June 2013) Available from Ebscohost database.

PR Newswire (2013b), 'Daily Intermittent Fasting is best for Calorie Restriction, Health and Weight loss', PR Newswire, US, 5 April, (online) (cited 30 June 2013) Available from Ebscohost database.

Shah, J. (2009) Supply Chain Management: Text and Cases, New Delhi, Pearson Education.

Singh, S.S. (2012) 'The "Most Important" Supply Chain Role 11', Supply Chain Diary (Sanjeevs), (online) (cited 17 December 2013) Available from URL: <2013http://supplychaindiary. blogspot.in/2012/02/most-important-supply-chain-role.html>.

Stipp, D. (2013) 'Is fasting good for you?', Scientific American, 308:1, pp. 23-24.

Vrat, P. (2011) 'Inventory Models and Human Body Food Supply Chain: Some Managerial Insights', Industrial Engineering Journal, 2:2, pp. 8-16

Zhang, G., Xie, L. and Li, D. (2006) 'A Study on Bionic Model of Knowledge Supply Chain in an Enterprise, Proceedings of I-KNOW' '06, pp. 126-133, 6-8, September, Graz, Austria.

Prem Vrat, Vice Chancellor \& Professor of Eminence, ITM University, Sector 23A, Gurgaon. Email: premvrat@itmindia.edu.

Alpana Agarwal, Research Scholar, ITM University, Sector 23 A, Gurgaon. Email: alpanaagarwal@itmindia.edu. 